\title{
Minat Baca dan Peran Orang Tua di Masa Pandemi COVID-19 Terhadap Keterampilan Membaca Bahasa Indonesia
}

\author{
Ni Made Sintya Aryandani ${ }^{*}$, Luh Putu Putrini Mahadewi2 ${ }^{2}$ I Made Citra Wibawa ${ }^{3}$ \\ 1,3 Program Studi Pendidikan Guru Sekolah Dasar, Universitas Pendidikan Ganesha, Singaraja, Indonesia \\ 2 Program Studi Ilmu Psikologi Pendidikan dan Bimbingan, Universitas Pendidikan Ganesha, SIngaraja, Indonesia
}

\section{ART ICLE INFO}

Article history:

Received July 12, 2021

Revised July 15, 2021

Accepted September 30, 2021

Available online October 25, 2021

Kata Kunci:

Minat, Orang Tua,

Keteampilan Membaca

Keywords:

Interest, Parents, Reading Ability

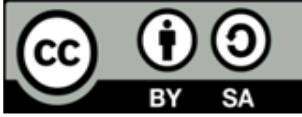

This is an open access article under the CC BY-SA license.

Copyright $($ C) 2021 by Author. Published by Universitas Pendidikan Ganesha.

\begin{abstract}
A B S T R A K
Keterampilan membaca bahasa Indonesia siswa mulai menurun di masa pandemi COVID-19. Hal tersebut dipengaruhi oleh randahnya minat baca, serta kurangnya perhatian orang tua di masa pandemi COVID-19. Tujuan penelitian ini untuk menganalisis hubungan minat baca dan peran orang tua di masa pandemi COVID-19 terhadap keterampilan membaca bahasa Indonesia. Jenis penelitian ini adalah penelitian ex post facto. Populasi dalam penelitian ini berjumlah 49 orang siswa. Metode yang digunakan dalam mengumpulkan data yaitu metode tes dan metode kuesioner. Instrumen yang digunakan untuk mengumpulkan data yaitu kuesioner. Teknik analisis data yang digunakan yaitu analisis statistik deskriptif dan analisis statistik inferensial. Berdasarkan hasil analisis maka terdapat hubungan yang signifikan minat baca dan keterampilan membaca bahasa Indonesia dengan $r_{x 1 y}=0,706$ dengan koefisien determinasi sebesar $49,8 \%$ sehingga terdapat hubungan yang signifikan peran orang tua di masa pandemi COVID-19. Keterampilan membaca bahasa Indonesia dengan $r_{x 2 y}=0,805$ dengan koefisien determinasi sebesar $64,7 \%$, secara simultan, terdapat hubungan yang signifikansi minat baca dan peran orang tua di masa pandemi COVID-19 terhadap keterampilan membaca Bahasa Indonesia dengan $r_{x 1 \times 2 y}=0,805$ dengan koefisien determinasi sebesar $65,9 \%$. Jadi ditemukan terdapat hubungan yang signifikan minat baca dan peran orang tua di masa pandemi COVID-19 terhadap keterampilan membaca Bahasa Indonesia. Implikasi penelitian ini yaitu peranan orang tua sangat penting untuk menumbuhkan minat baca siswa di masa pandemi covid-19.
\end{abstract}

\section{A B S T RACT}

Students' Indonesian reading skills began to decline during the COVID-19 pandemic. This was influenced by the low interest in reading, as well as the lack of parental attention during the COVID-19 pandemic. The purpose of this study was to analyze the relationship between reading interest and the role of parents during the COVID-19 pandemic on Indonesian reading skills. This type of research is ex post facto research. The population in this study amounted to 49 students. The method used in collecting data is the test method and the questionnaire method. The instrument used to collect data is a questionnaire. The data analysis technique used is descriptive statistical analysis and inferential statistical analysis. Based on the results of the analysis, there is a significant relationship between reading interest and Indonesian reading skills with $r \times 1 y=0.706$ with a coefficient of determination of $49.8 \%$ so that there is a significant relationship with the role of parents during the COVID-19 pandemic. Indonesian reading skills with rx2y $=0.805$ with a determination coefficient of $64.7 \%$, simultaneously, there is a significant relationship between reading interest and the role of parents during the COVID-19 pandemic on Indonesian reading skills with rx1x2y = 0.805 with a determination coefficient of $65,9 \%$. So it was found that there was a significant relationship between reading interest and the role of parents during the COVID-19 pandemic on Indonesian reading skills. The implication of this research is that the role of parents is very important to foster student interest in reading during the covid-19 pandemic.

\section{PENDAHULUAN}

Saat ini Indonesia bahkan dunia digemparkan dengan virus corona yang dapat menyebabkan kematian pada manusia (Batubara \& Batubara, 2020; Handayani et al, 2020; Mehrsafar, Moghadam, Sánchez, \& Gazerani, 2021). Dampak dari corona virus ini sangat meluas mulai dari ekomoni, politik, sosial, budaya, dan pendidikan (Durnali, 2020; Putri, 2020). Dampak yang paling menonjol yaitu dalam bidang pendidikan di semua tingkatan 
pendidikan mulai dari TK sampai dengan perguruan tinggi (Maulana \& Hamidi, 2020; Yoga Purandina \& Astra Winaya, 2020). Kebijakan yang dikeluarkan dimasa darurat penyebaran COVID-19 dijelaskan bahwa proses pembelajaran dilakukan di rumah melalui proses pembelajaran daring atau jarak jauh untuk mencegah rantai penularan (Dewi, 2020b; Garad, Al-Ansi, \& Qamari, 2021). Saat ini seluruh pembelajaran dilakukan dengan daring, sehingga guru harus )menyiapkan pembelajaran dengan matang (Dewi, 2020a; Fitriyani \& Sari, 2020). Pembelajaran daring dilakukan melalui media WhatsApp, Zoom Meeting, Google Forms, Google Meet, Google Classroom sesuai kesepakatan sekolah masing-masing (Malyana, 2020). Pembelajaran daring harus berjalan dengan baik sehingga tujuan pembelajaran juga dapat tercapai secara maksimal. Selain itu, pembelajaran jarak jauh juga diharapkan dapat meningkatkan keterampilan anak (Baber, 2021; Shaik Alavudeen et al., 2021). Salah satu keterampilan yang dibutuhkan oleh siswa adalah keterampilan membaca. Keterampilan ini sangat dibutuhkan dalam pembelajaran (Agathi Dian, Kristiantari, \& Ganing, 2015; J. Warsihna, 2016; Jaka Warsihna, 2016). Selain itu, orang tujua harus memberikan dukungan terhadap pengembangan keterampilan membaca. Selain itu diharapkan orang tua dapat memfasilitasi anak dengan menyediakan bahan bacaan sehingga dapat tumbuh minat baca pada siswa

Namun permasalahan yang terjadi saat ini masih banyak siswa yang memiliki minat baca yang rendah (Christianti, 2013; Muhammad, Sholichah, \& Aziz, 2019). Selain itu orang tua juga mengalami kesulitan memberikan fasilitas seperti telepon yang dapat digunakan oleh anak untuk pembelajaran daring. Selain itu, siswa yang tinggal didaerah pelosok juga kesulitan dalam mendapatkan jaringan internet sehingga pembelajaran daring tidak berjalan dengan maksimal (Abidah et al, 2020; Ayuni, Marini, Fauziddin, \& Pahrul, 2021). Berdasarkan hasil wawancara dengan guru di SD Negeri 2 Gunung Salak pembelajaran daring baik digunakan untuk peserta didik. Pada awal pembelajaran, materi diberikan melalui file dengan format Microsoft Word kemudian siswa membaca, tapi lama-lama siswa menjadi bosan. Kemudian pemberian materi berikutnya melalui video, siswa sangat bersemangat untuk mengikuti kegiatan pembelajaran secara daring. Selain itu beberapa kali siswa diberikan soal melalui Google Form, siswa sangat bersemangat dikarenakan mereka bisa langsung melihat jawaban yang benar dan jawaban yang salah. Penggunaan Zoom Meeting sangat jarang digunakan, hal ini disebabkan tidak semua siswa memiliki akses jaringan internet yang memadai serta orang tua yang lebih sering membawa gawai telepon pintar bekerja. Selain itu, berdasarkan hasil wawancara bersama Wali Kelas V di SD Negeri 1 Megati Kecamatan Selemadeg Timur. Beliau menyampaikan di masa pandemi COVID-19 minat baca siswa mulai menurun. Penyebab utama yaitu karna pembelajaran dilakukan secara daring, sumber buku untuk dipelajari dirumah sedikit serta diterangkan pula oleh beliau kebanyakan orang tua siswa sibuk bekerja sehingga tidak bisa selalu mengikuti kegiatan pembelajaran daring dengan tepat waktu.

Keterampilan membaca adalah dasar untuk dapat mengikuti pembelajaran. Membaca merupakan modal yang paling utama untuk dapat mengerti dan memahami pembelajaran lainnya (Asna \& Mimi, 2016; Christianti, 2013). Keterampilan membaca sangat penting untuk diasah karena melalui keterampilan ini seseorang akan dapat mengambil keputusan dan mengasah kemampuan otak (Heldisari, 2020a; Pertiwi, Sumarno, \& Dwi, 2019). Siswa yang memiiki keterampilan membaca dengan baik akan dapat memahami isi dari bacaan yang dibacanya sehingga akan lebih mudah memahami materi pembelajaran (Antara \& Aditya, 2019; Maryani, Ichsan, \& Khairunnisa, 2017). Sehingga keterampilan membaca ini adalah keahlian yang akan didapatkan oleh siswa melalui kegiaan membaca sehingga dapat memperoleh ilmu dari sebuah tulisan. Faktor yang mempengaruhi keterampilan membaca yaitu faktor fisiologis, intektual, lingkungan, dan psikologis (Afrianti \& Wirman, 2020; Astuti \& Istiarini, 2020). Minat baca sangat diperlukan agar keterampilan membaca akan meningkat. minat membaca ini juga dapat timbul karena dipengaruhi oleh beberapa faktor yaitu ekstrinsik dan intrisik (Heldisari, 2020b; Zhao \& Wu, 2021). Salah satu faktor ekstrinsik yang akan mempengaruhi keterampilan membaca anak adalah peran orang tua. Orangtua merupakan orang yang paling dan sangat dengan dengan anak (Junianto \& Wagiran, 2013; Karima \& Kurniawati, 2020). Orangtua adalah pendidik utama bagi seorang anak. Orangtua wajib memberikan dukungan terhadap perkembangan membaca pada anak (Maufur \& Puadah, 2015; Saputro, 2019). Dukungan yang dapat diberikan seperti peran orang tua mendampingi anaknya ketika mereka sedang belajar dan memfasilitasi anak dengan menyediakan bahan bacaan di rumah sehingga dapat menumbuhkan minat baca anak (Creed, Conlon, \& Zimmer-Gembeck, 2012; Wang \& Liu, 2021).

Temuan penelitian sebelumnya menyatakan bahwa orangtua dapat membantu membimbing pengerjaan tugas, memberikan fasilitas belajar sehingga dapat meningkatkan pembelajaran daring (Daheri, Juliana, Deriwanto, \& Amda, 2020; Pranata, 2014). Temuan penelitian lainnya juga menyatakan bahwa ditemukan hubungan positif antara minat membaca dan hasil belajar siswa (Ni, Lu, Lu, \& Tan, 2021; Sari, 2020). Belum adanya kajian mengenai minat baca dan peran orangtua di masa pandemi Covid-19 terhadap keterampilan membaca Bahasa Indonesia. Perlunya analisis peran orangtua dalam pembelajaran. Penelitian ini bertujuan untuk menganalisis minat baca dan peran orangtua di masa pandemi Covid-19 terhadap keterampilan membaca Bahasa Indonesia Kelas V di SD Negeri 1 Megati Kecamatan Selemadeg Timur. Kelebihan penelitian ini yaitu tidak hanya menganalisis minat membaca siswa terhadap keterampilan membaca, namun menganalisis peran orang tua di masa pandemi Covid-19. Adanya penelitian ini diharapkan dapat membangkitkan minat baca siswa di masa pandemi Covid-19. 


\section{METODE}

Penelitian ini dilakukan di SD Gugus I Kecamatan Selemadeg Timur tahun ajaran 2020/2021. Penelitian ini berjenis ex post facto Penelitian ex post facto merupakan penelitian untuk mengetahui hubungan sebab akibar dari dua atau lebih variabel. Hal tersebut sejalan dengan penelitian ini yaitu mencari tahu hubungan variabel bebas minat baca $\left(\mathrm{X}_{1}\right)$ dan peran orang tua di masa pandemi COVID-19 $\left(\mathrm{X}_{2}\right)$ dengan variabel terikat keterampilan membaca bahasa Indonesia (Y) siswa kelas V SD Gugus I Kecamaran Selamdeg Timur Tahun Ajaran 2020/2021. Pola hubungan variabel tersebut dapat digambarkan pada gambar 1. Populasi dalam penelitian ini adalah seluruh siswa kelas V di SD Gugus I Kecamatan Selemadeg Timur yaitu sebanyak 49 orang. Dalam penelitian ini seluruh populasi digunakan sebagai sampel. Adapun sampel dari penelitian ini terdiri dari 11 orang laki-laki dan 9 orang perempuan di SD Negeri 1 Megati, 8 orang laki-laki dan 8 orang perempuan di SD Negeri 2 Megati, 4 orang laik-laki dan 2 orang perempuan di SD Negeri 1 Gunung Salak, 5 orang laki-laki dan 2 orang perempuan di SD Negeri 2 Gunung Salak. Dalam penelitian ini menggunakan teknik sampilng total, hal tersebut disebabkan oleh jumlah populasi penelitian kurang dari 100 orang. Metode yang digunakan dalam mengumpulkan data yaitu metode tes dan metode kuesioner. Jenis kuesioner yang digunakan dalam penelitian ini adalah kuesioner tertutup dimana peserta didik hanya bisa memilik alternatif jawaban yang sudah disediakan pada lembar kuesione. Data yang diperoleh melalui metode tes yaitu keterampilan membaca bahasa Indonesia, sedangkan data yang diperoleh melalui kuesioner dengan penskoran instrumen yang tidak ditampilkan skor perolehannya.

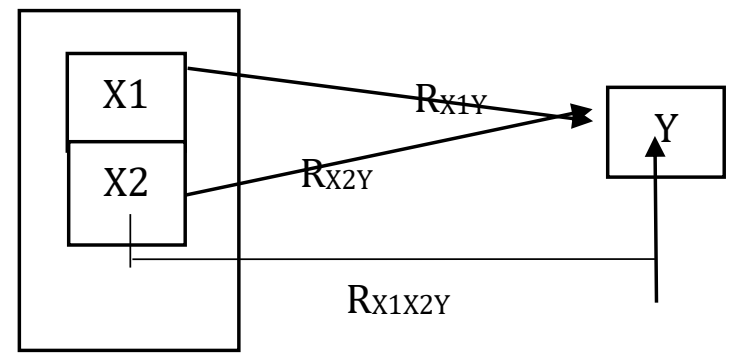

Gambar 1. Pola Hubungan variabel

Keterangan:

$\mathrm{X}_{1} \quad$ : Minat Baca

$\mathrm{X}_{2} \quad$ : Peran Orang Tua di Masa Pandemi COVID-19

Y : Keterampilan Membaca Bahasa Indonesia

$\mathrm{R}_{\mathrm{X} 1 \mathrm{Y}} \quad$ : Korelasi $\mathrm{X}_{1}$ terhadap Y Subjek Penelitian

Rx2Y : Korelasi $X_{2}$ terhadap Y Subjek Penelitian

Rx1X2Y : Korelasi $X_{1}$ dan $X_{2}$ terhadap Y Subjek Penelitian

Skala yang digunakan untuk mengukur instrumen minat baca dan peran orang tua di masa pandemi COVID-19 adalah skala likert. Pertama dilakukan uji pengujian instrumen penelitian dengan menggunakan uji validitas expert judgment. Uji validitas yang digunakan dalam penelitian ini yaitu uji validitas isi dan uji validitas butir. Setelah itu dilakukan uji reliabelitas untuk mengukut keajegan suatu kuesioner apabila kuesioner tersebut digunakan lebih dari satu kali maka akan tetap sama. Pada uji analisis reliabelitas menggunakan rumus Alpha Cronbach. Kuesioner disusun berdasarkan kisi-kisi yang memuat indikator. Indikator minat baca dalam penelitian ini meliputi kesenangan membaca, kesadaran akan manfaat membaca, frekuensi membaca, kuantitas sumber bacaan. Kemudian disusunlah kisi-kisi berdasarkan instrumen pada tabel 1 dan 2. Sebelum melakukan uji hipotesis yang menerapkan suatu analisis uji regresi linier sederhananya serta analisis uji regresi linier berganda dapat dilakukan dengan menghitung uji prasyarat analisis yaitu normalitas, uji linieritasnya, uji multikolinearitasnya serta juga uji heteroskedastisitasnya. Teknik analisis data yang digunakan yaitu analisis statistik deskriptif dan analisis statistik inferensial. Uji normalitas memiliki tujuan untuk mengetahui persebaran frekuensi skornya di setiap variabel yang memiliki distribusi normal ataupun tidak maka diaplikasikan analisis Kolmogrov-smirnov. Selanjutnya uji linieritas dilakukan untuk mengetahui suatu bentuk dari hubungan suatu variabel terikat dan variabel bebas untuk itu dilaksanakan dapat dilaksanakan mengunakan analisis of varians. Uji multikolonieritas memiliki tujuan untuk mengetahui dalam satu model ganda dapat diperoleh hubungan antar vairabel bebasnya dilaksanakan dengan menguji nilai VIF atau Variance Inflation Factor ataupun niali Tol atau Tolerance. Uji heteroskedastisitas untuk mengetahui ada atau tidak ketidaksamaan variannya terhadap residual terhadap model resgresinya. 
Tabel 1. Kisi-Kisi Instrumen Minat Baca

\begin{tabular}{lllc}
\hline No. & Aspek & Indikator & Jumlah Item \\
\hline 1 & Kesenangan membaca & Rasa senang dalam kegiatan membaca & 4 \\
& & Membaca atas keinginana sendiri & 4 \\
2 & Kesadaran akan manfaat membaca & Kesadaran akan pentingnya membaca & 4 \\
3 & Frekuensi membaca & Intensitas membaca & 3 \\
4 & Kualitas sumber bacaan & Jumlah dan keberagaman bacaan & 3 \\
& & Usaha mendapat sumber bacaan & 2 \\
\hline
\end{tabular}

Tabel 2. Kisi-Kisi Instrumen Peran Orang Tua di Masa Pandemi COVID-19

\begin{tabular}{lllc}
\hline No. & Aspek & Indikator & Jumlah Item \\
\hline 1 & Pembimbing & Usaha orang tua dalam mengawasi anak belajar & 6 \\
& & Usaha orang tua menemani anak belajar & 6 \\
2 & Motivator & Pemberian motivasi belajar & 3 \\
3 & Fasilitator & Pemberian Fasilitas belajar & 6 \\
\hline & & Jumlah & $\mathbf{2 0}$ \\
\hline
\end{tabular}

\section{HASIL DAN PEMBAHASAN}

Hasil

Berdasarkan hasil pengujian dengan menggunakan analisis deskriptif dan inferensial. Data yang diperoleh dalam penelitian ini adalah data minat baca, peran orang tua di masa pandemi COVID-19 dan keterampilan membaca bahasa Indonesia siswa kelas V SD Gugus I Kecamatan Selemadeg Timur. Berikut data hasil penelitian disajikan pada Tabel 3. Data hasil analisis distribusi minat baca berada pada predikat skor 79,9 $\leq$ $\mathrm{X} \leq 99$,9. Maka dapat diketahui bahwa minat baca berada pada predikat sangat baik. Data hasil analisis distribusi peran orang tua di masa pandemi COVID-19 berada pada predikat skor $66,6 \leq \mathrm{X} \leq 79,9$. Maka dapat diketahui bahwa peran orang tua di masa pandemi COVID-19 berada pada predikat baik. Data hasil analisis distribusi keterampilan membaca bahasa Indonesia berada pada predikat skor $62,5 \leq \mathrm{X} \leq 77,5$. Maka dapat diketahui bahwa keterampilan membaca bahasa Indonesia berada pada predikat baik.

Tabel 3. Hasil Analisis Deskriptif

\begin{tabular}{lccc}
\hline & $\begin{array}{c}\text { Keterampilan Membaca Bahasa } \\
\text { Indonesia }\end{array}$ & $\begin{array}{c}\text { Minat Baca } \\
\text { (X1) }\end{array}$ & $\begin{array}{c}\text { Peran Orang Tua di Masa Pandemi } \\
\text { COVID-19 (X2) }\end{array}$ \\
\hline Mean & 68,2 & 80,2 & 74,57 \\
Median & 67,82 & 79,85 & 75,78 \\
Modus & 69,58 & 78,75 & 76,18 \\
Standar Deviasi & 12,01 & 7,01 & 7,80 \\
\hline Predikat & Baik & Sangat Baik & Baik \\
\hline
\end{tabular}

Sebelum melakukan uji hipotesis, diawali dengan uji asumsi terlebih dahulu yaitu uji nomalitas, uji linieritas, serta uji multikolonieritas. Pengujian tersebut dilakukan untuk mengetahui apakah data keterampilan membaca bahasa Indonesia, minat baca, dan peran orang tua di masa pandemu COVID-19 berdistribusi normal atau tidak, dengan menggunakan teknik Kolmogrov-Smirnov dibantu dengan aplikasi SPPS Statistic 17.0 dengan ketentuan apabila hasil uji Kolmogrov-Smirnov dengan $r \geq 0,05$ makan data tersebut berdistribusi normal sedangkan bila $r<0,05$ maka data tersebut tidak berdistribusi normal. Data hasil uji normalitas keterampilan membaca bahasa Indonesia diperoleh skor kolmogrov-smirnov sebesar 1,260 > 0,05 sehingga dapat dikatakan data tersebut berdistribusi normal. Diperoleh hasil uji normalitas data minat baca dengan jumlah skor kolmogrov-smirnov sebesar 1,125 > 0,05 sehingga dapat dikatakan data tersebut berdistribusi normal. Selanjutnya diperoleh hasil uji normalitas data peran orang tua di masa pandemi COVID-19 dengan jumlah skor kolmogrov-smirnov sebesar 0,979 > 0,05 sehingga data tersebut dapat dikatakan berdistribusi normal.

Dalam penelitian ini uji linieritas di bantu dengan menggunakan applikasi SPSS Statistic 17.0. Penarikan kesimpulan dalam penelitian ini dilihat dari hasil signifikansi Linierity dan Deviation from Linierity. Variabel X dan Y dikatakan linier apabila hasil signifikansi Linierity lebih rendah jika dibandingan dengan 0,05 (Deviation from linierity $>0,05$ ). Sedangkan variabel $\mathrm{X}$ dan $\mathrm{Y}$ dapat dikatakan tidak memiliki hubungan jika hasil perhitungan menunjukkan signifikansi Deviation from Linierity lebih tinggi dibandingkan dengan 0,05 (Deviation from linierity $<0,05)$. Diperoleh hasil uji linieritas data minat baca $\left(\mathrm{X}_{1}\right)$ terhadap keterampilan membaca bahasa Indonesia (Y) dengan linearity sebesar 0,00 < 0,05 dan deviation from linearity seberar 0,165 $<$ 0,05 sehingga 
data tersebut dapat dinyatakan linier. Selanjutnya hasil uji linieritas data peran orang tua di masa pandemi covid-19 (X2) terhadap keterampilan membaca bahasa Indonesia (Y) dengan linearity sebesar 0,00>0,05 dengan deviation from linearity sebesar 0,127<0,05 sehingga data tersebut dapat dinyatakan linier.

Uji mulitkolonieritas dalam penelitian ini berbantuan aplikasi SPSS Statistic 17.0 dengan melakukan uji regresi. Dalam pengambilan keputusan menggunakan aturan yaitu jika di peroleh dalam kolom VIF dan Tolerance mendekati angka 1, maka dapat dinyatakan bahwa seluruh kelompok data tidak terjadi multikolonieritas. Setelah melaukan uji multikolonieritas menggunakan SPSS Statistic 17.0 diperoleh nilai hitung tolerance senilai 0,275 dan VIF 3.640. Dari data tersebut nilai VIF dibawah 10,00 dan tolerance diatas 0,10. Sehingga dapat disimpulkan bahwa tidak terjadi gejala multikolonieritas dalam model regresi dan memenuhi uji prasyarat analisis. Dalam penelitian ini terdapat tiga hipotesis yang akan diuji kebenarannya. Hipotesis pertama dan kedua diuji menggukana teknik regresi sederhana dengan korelasi Product Moment dengan berbantuan aplikasi SPSS Statistic 17.0. Hipotesis ketiga diuji menggunakan regresi berganda dengan berbantuan aplikasi SPSS Statistic 17.0. Berdasarkan hasil analisis korelasi berbantuan aplikasi SPSS Statistic 17.0 dengan teknik analisis Pearson yang telah dilakukan, untuk uji hipotesis pertama diperoleh $r_{\text {hitung }}$ sebesar $=0,706$ dengan drajat kebebasan $(\mathrm{df}=\mathrm{N}-2)$, pada taraf signifikansi 5\% dapat diperoleh $\mathrm{df}=49-2=47$ dan diperoleh $\mathrm{r}_{\text {tabel }}$ sebesar $=$ 0,281 . Dengan demikian $r_{\text {hitung }}$ sebesar 0,76 lebih besar dari $r_{\text {tabel }}=0,281$. Dengan koefisien determinasi yaitu 49,8\%. Hal tersebut dikarenakan $\mathrm{r}_{\text {hitung }} 0,706>0,281 \mathrm{r}_{\text {tabel }}$ dapat dinyatakan $\mathrm{H}_{1}$ diterima sehingga terdapat hubungan yang signifikan minat baca terhadap keteramilan membaca bahasa Indonesia siswa kelas V SD Gugus I Kecamatan Selemadeg Timur Tahun Ajaran 2020/2021, dan $\mathrm{H}_{0}$ ditolak sehingga tidak terdapat hubungan yang signifikan minat baca terhadap keterampilan membaca bahasa Indonesia siswa kelas V SD Gugus I Kecamatan Selemadeg Timur Tahun Ajaran 2020/2021.

Dalam uji hipotesis kedua diperoleh rhitung sebesar 0,805 dengan drajat kebebasan ( $\mathrm{df}=\mathrm{N}-2$ ), pada taraf signifikansi $5 \%$ dapat diperoleh $\mathrm{df}=49-2=47$ dan diperoleh $r_{\text {tabel }}$ sebesar 0,281. Dengan demikian $r_{\text {hitung }}$ sebesar 0,805 lebih besar dari $r_{\text {tabel }}=0,281$. Dengan koefisien determinasi yaitu $64,7 \%$. Hal tersebut dikarenakan $r_{\text {hitung }}$ $0,805>0,281 r_{\text {tabel }}$ dapat dinyatakan $\mathrm{H}_{1}$ diterima sehingga terdapat hubungan yang signifikan peran orang tua di masa pandemi COVID-19 terhadap keterampilan membaca bahasa Indonesia siswa kelas V SD Gugus I Kecamatan Semadeg Timur Tahun Ajaran 2020/2021, dan $\mathrm{H}_{0}$ ditolak sehingga tidak terdapat hubungan yang signifikan peran orang tua di masa pandemi COVID-19 terhadap keterampilan membaca bahasa Indonesia siswa kelas V SD Gugus I Kecamatan Selemadeg Timur Tahun Ajaran 2020/2021. Hasil analisis regresi berganda dengan teknik koefisien dengan persamaan $\mathrm{Y}=-26,836+0,130 \mathrm{X}_{1}+1,302 \mathrm{X}_{2}$, persamaan ini menunjukkan a=-26,836, hasil tersebut menampilkan angka konstanta sehingga bermakna jika ditemukan minat baca $\left(\mathrm{X}_{1}\right)$ dan peran orang tua pandemi COVID-19 (X2) maka nilai keterampilan membaca bahasa Indonesia senilai -26,836. Berdasarkan hal tersebut diketahui nilai koefisien minat baca $\left(\mathrm{X}_{1}\right)$ senilai 0,130 yang bermakna setiap 1\% pengingkatan minat baca berakibat pada peningkatan hasil keterampilan membaca bahasa Indonesia senilai 0,130 , nilai koefisien bernilai positif dengan manka ditemukan hubungan positif serta nilai signifikansi senilai 0,001 lebih rendah jika dibandingan dengan 0,05 hasil tersebut mengindikasikan terdapat korelasi yang signifikan minat baca terhadap keterampilan membaca Bahasa Indonesia. sedangkan, nilai koefisien peran orang tua di masa pandemi COVID-19 $\left(\mathrm{X}_{2}\right)$ senilai 1,302 yang bermakna setiap 1\% peningkatan peran orang tua di masa pandemi COVID-19 mengakibatkan terjadi peningkatan hasil belajar senilai 1,302. Nilai koefisien bernilai positif $(+)$ yang bermakna ditemukan korelasi yang positif serta nilai signifikansi senilai 0,000 rendah jika dibandingkan dengan 0,05. Hasil tersebut mengindikasikan korelasi yang signifikan peran orang tua di masa pandemi COVID-19 terhadap keterampilan membaca bahasa Indonesia. Hubungan minat baca dan peran orang tua di masa pandemi COVID-19 terhadap keterampilan membaca bahasa Indonesia senilai 0,805. Sedangkan koefisien determinasinya senilai 0,649 atau 64,9\%. Rhitung senilai 0,805 kemudian dibandingkan $\mathrm{r}_{\text {tabel }}$ dengan derajat kebebasan $(\mathrm{df}=\mathrm{N}-2)$, pada taraf signifikansi 5\% didapatkan $\mathrm{df}=49-2=47$ serta diperoleh $r_{\text {tabel }}=0,291$ sehingga $r_{\text {hitung }}$ lebih besar dari $r_{\text {tabel }}$. Berikut hasil pengujian hipotesis di atas dilihat pada Tabel 6.

Tabel 6. Ringkasan hasil uji hipotesis

\begin{tabular}{lccccc}
\hline \multirow{2}{*}{ Variabel } & \multirow{2}{*}{ rhitung } & \multirow{2}{*}{ rtabel } & Koefisien determinasi & \multicolumn{2}{c}{ Hipotesis } \\
\cline { 5 - 6 } & & & & Ho & Diterima \\
$r_{x 1 y}$ & 0,706 & 0,288 & $48,8 \%$ & Ditolak & Diterima \\
$r_{x 2 y}$ & 0,805 & 0,288 & $64,7 \%$ & Ditolak & Diterima \\
\hline
\end{tabular}

Hal tersebut mengindikasikan bahwa ditemukan hubungan yang signifikan antara miant baca dan peran orang tua di masa pandemi COVID-19 terhadap keterampilan membaca bahasa Indonesia, sehingga $\mathrm{H}_{3}$ ditemukan hubungan yang signifikan minat baca dan peran orang tua di masa pandemi COVID-19 terhadap keterampilan membaca bahasa Indonesia siswa kelas V SD Gugus I Kecamatan Selemadeg Timur Tahun Ajaran 2020/2021 diterima, sehinga $\mathrm{HO}_{3}$ : tidak ditemukan hubungan yang signifikan minat baca dan peran orang tua di masa pandemi COVID-19 terhadap keterampilan membaca bahasa Indonesia siswa kelas V SD Gugus I Kecamatan 
Selemadeg Timur Tahun Ajaran 2020/2021 ditolak. Keterampilan membaca dipengaruhi oleh beberapa faktor dari hubungan minat baca dan peran orang tua di masa pandemi COVID-19 sebagai berikut. Pertama, terdapat hubungan minat baca terhadap keterampilan membaca bahasa Indonesa hal tersebut terjadi karena apabila siswa memiliki minat baca yang tinggi maka keterampilan membaca bahasa Indonesia mereka akan lebih baik (Dafit, Mustika, \& Melihayatri, 2020; Widodo et al, 2020). Apabila minat baca siswa rendah akan memberikan dampak berupa buruknya keterampilan membaca bahasa Indonesia siswa (Nafisah, 2016; Soekirno, 2011). Dalam penelitian ini ditemukan bahwa keberhasilan yang diperoleh oleh siswa khususnya pada bidang keterampilan membaca bahasa Indonesia di pengaruhi oleh minat baca. Minat baca siswa di pengaruhi oleh indikator yang dimodifikasi dari perpaduan pendapat Sudarsana dan Dalman yaitu rasa senang dalam membaca, membaca atas keinginana sendiri, kesadaran akan pentingnya membaca, intensistas membaca, jumlah dan keberagaman bacaan, usaha mendapat sumber baca (Fitri, 2019; Salma \& Mudzanatun, 2019; Sari, 2020). Ratarata minat baca siswa dalam penelitian ini berada dalam kategori sangat baik. Akan tetapi ada juga beberapa siswa yang memilki minat baca rendah, kemudian keterampilan membaca bahasa Indonesia siswa menjadi kurang optimal. Minat baca berkontribusi terhadap keterampilan membaca pemahaman (Halawa, Ramadhan, \& Gani, 2020; Ramandanu, 2019). Hal tersebut berarti minat baca memilki kaitan yang erat dengan keterampilan membaca Bahasa Indonesia.

Kedua, terdapat hubungan peran orang tua di masa pandemi COVID-19 terhadap keterampilan membaca Bahasa Indonesia. Hal itu disebabkan karena peran orang tua di masa pandemi COVID-19 memberikan pengaruh terhadap keterampilan membaca bahasa Indonesia. Peran orang tua sangat dibutuhkan untuk memberikan edukasi tentang pandemi yang saat ini sedang mewabah (Rosalina, Widyasari, Ismi, \& Hapsari, 2010; Sakti, 2021; Wijayanti \& Fauziah, 2020). Apabila orang tua mendampingi proses pembelajaran siswa secara daring dengan baik yaitu menemani siswa belajar maka demikian keterampilan membaca bahasa Indonesia menjadi lebih baik (Halimah, 2019; Ulfah \& Rahmah, 2017). Sedangkan apabila orang tua tidak memberikan perhatian secara khusus terhadap anaknya maka keterampilan membaca bahasa Indonesia siswa menjadi kurang optimal. Maka dari itu diperlukan peran orang tua selama pembelajaran daring berlangsung sehingga keterampilan membaca bahasa Indonesia siswa menjadi optimal (Maufur \& Puadah, 2015; Pranata, 2014). Orang tua memiliki tugas sebagai pembimbing, pendidik, penjaga, pengembang serta pengawas (Kurniati, Nur Alfaeni, \& Andriani, 2020; Suastariyani \& Tirtayani, 2020). Peran orang tua dalam melaksanakan pembelajaran dimasa pandemi COVID-19 sangat memberikan pengaruh terhadap tingkat penerapan pembelajaran dirumah. Pengaruh yang paling terasa yaitu orang tua sebagai motivator kepada minat dan motivasi anak meningkatkan bila diberi kepercayaan dan tanggung jawab mengimplikasikan bakat atau potensi diri yang dikembangkan maupun dimiliki (Mufaziah \& Fauziah, 2020; Sakti, 2021).

Ketiga terdapat hubungan minat baca dan peran orang tua terhadap keterampilan membaca Bahasa Indonesia siswa yang disebabkan karena keterampilan membaca Bahasa Indonesia dapat dipengaruhi secara simultan oleh faktor minat baca dan peran orang tua di masa pandemi COVID-19. Keinginan membaca dan kesadaran orang tua dalam mendampingi anak dalam proses pembelajaran akan menciptakan keterampilan membaca Bahasa Indonesia siswa menjadi optimal (Lestari \& Zulmiyetri, 2019; Jaka Warsihna, 2016). Asumsi tersebut diperkuat dengan temuan sebelumnya yang menyatakan bahwa minat baca memiliki hubungan yang signifikan dengan kemampuan membaca pemahaman (Antara \& Aditya, 2019). Sejalan dari hasil penelitian tersebut, didapatkan minat baca dan peran orang tua di masa pandemi COVID-19 secara simultan berkorelasi terhadap keterampilan membaca Bahasa Indonesia. Minat baca tidak selalu mempengaruhi keterampilan membaca Bahasa Indonesia anak didik. Begitu pula peran orang tua yang kurang perhatian terhadap anak memberikan pengaruh terhadap keterampilan membaca Bahasa Indonesia yg dimiliki oleh anak didik. Asumsi tersebut sesuai atas kesimpulan yang di kemukan oleh beberapa penelitian yang telah dipaparkan sebelumya, yaitu keterampilan membaca Bahasa Indonesia dipengaruhi oleh dua faktor yaitu minat baca dan peran orang tua di masa pandemi COVID-19. Temuan penelitian sebelumnya juga menyatakan bahwa menyatakan peran orang tua sangat penting dlam pembelajaran daring (Mirzon Daheri, Juliana, Deriwanto, 2020; Yulianingsih, Suhanadji, Nugroho, \& Mustakim, 2020). Temuan penelitian sebelumnya juga menyatakan bahwa orang tua memiliki peran dalam meningkatkan keterampilan literasi anak dimasa pandemi COVID-19 (Widyastuti, Kurniawan, \& Rintayati, 2021). Keterkaitan antara peran orang tua di masa pandemi COVID-19 dan keterampilan membaca Bahasa Indonesia yang tidak dapat dipungkiri bahwa perbedaan peran orang tua dalam mendampingi anak belajar akan memnyebabkan tidak optimalnya keterampilan membaca Bahasa Indonesia. Kelebihan penelitian ini yaitu tidak hanya menganalisis pada minat baca saja, namun peran orang tua juga dilibatkan. Penelitian sebelumnya hanya menganalisis pada peran orang tua dalam pembelajaran daring. Implikasi penelitian ini yaitu peranan orang tua sangat penting untuk meningkatkan keterampilan membaca pada siswa. Orang tua yang aktif dan mendukung anaknya ketika belajar, maka siswa akan memiliki kemampuan membaca yang optimal. Sebaliknya apabila orang tua tidak memperhatikan anaknya ketika sedang belajar karena sibuk bekerja, maka keterampilan membaca Bahasa Indonesia yang dimiliki oleh siswa menjadi kurang optimal. Dari asumsi tersebut, maka keterampilan membaca Bahasa Indonesia dipengaruhi oleh peran orang tua di masa pandemi COVID-19. 


\section{SIMPULAN}

Terdapat hubungan yang signifikan antara minat baca dan peran orang tua terhadap keterampilan membaca bahasa Indonesia serta di masa pandemi covid-19. Secara simultan terdapat hubungan minat baca dan peran orang tua di masa pandemi COVID-19 terhadap keterampilan membaca Bahasa Indonesia. Direkomendasikan kepada orang tua untuk selalu memberikan motivasi dan mendampingi anak dalam belajar sehingga dapat meningkatkan keterampilan membaca pada anak.

\section{DAFTAR PUSTAKA}

Abidah, A., Hidaayatullaah, H. N., Simamora, R. M., Fehabutar, D., \& Mutakinati, L. (2020). The Impact of Covid-19 to Indonesian Education and Its Relation to the Philosophy of "Merdeka Belajar." Studies in Philosophy of Science and Education, 1(1), 38-49. https://doi.org/https://doi.org/10.46627/sipose.v1i1.9.

Afrianti, Y., \& Wirman, A. (2020). Penggunaan Media Busy Book Untuk Menstimulasi Kemampuan Membaca Anak. Jurnal Pendidikan Tambusai, 4(2). https://doi.org/10.31004/jptam.v4i2.578.

Agathi Dian, I. A. A., Kristiantari, R. M. G., \& Ganing, N. (2015). Guru Terhadap Hasil Belajar Pengetahuan Bahasa Indonesia ( Keterampilan Membaca ) Tema Cita-Citaku Pada Siswa Kelas IV SD Desa Peguyangan. Mimbar PGSD Undiksha, 3(1). http://dx.doi.org/10.23887/jjpgsd.v3i1.5172.

Antara, \& Aditya, P. (2019). Pengaruh Model Pembelajaran Kontekstual Terhadap Kemampuan Membaca Permulaan Anak. Mimbar Ilmu, 24. http://dx.doi.org/10.23887/mi.v24i2.21263.

Asna, \& Mimi. (2016). Peningkatan Hasil dan Kemampuan Membaca Intensif Siswa Kelas IV pada Pembelajaran Bahasa Indonesia dengan Model Pembelajaran Word Square di SD Negeri 27 Batang Anai. Jurnal Konseling Dan Pendidikan, 4(2), 74 - 78. https://doi.org/10.29210/166\%y.

Astuti, \& Istiarini. (2020). Upaya Meningkatkan Kemampuan Membaca Permulaan Anak Usia 5-6 Tahun Melalui Media Puzzle di PAUD Flamboyan Sukasari Kota Tangerang. Ceria: Jurnal Program Studi Pendidikan Anak Usia Dini, 8(2). http://dx.doi.org/10.31000/ceria.v11i2.2338.

Ayuni, D., Marini, T., Fauziddin, M., \& Pahrul, Y. (2021). Kesiapan Guru TK Menghadapi Pembelajaran Daring Masa Pandemi Covid-19. Jurnal Obsesi : Jurnal Pendidikan Anak Usia Dini, 5(1). https://doi.org/10.31004/obsesi.v5i1.579.

Baber, H. (2021). Modelling the acceptance of e-learning during the pandemic of COVID-19-A study of South Korea. The International Journal of Management Education, 19(2). https://doi.org/10.1016/j.ijme.2021.100503.

Batubara, H. H., \& Batubara, D. S. (2020). Penggunaan Video Tutorial untuk Mendukung Pembelajaran Daring di Masa Pandemi Virus Corona. Jurnal Madrasah Ibtidaiyah, 5(2), 78-84. /http://dx.doi.org/10. 31602/muallimuna.v5i2.2950.

Christianti, M. (2013). Membaca dan Menulis Permulaan Untuk Anak Usia Dini. Jurnal Pendidikan Anak, 2(2). https://doi.org/10.21831/jpa.v2i2.3042.

Creed, P. A., Conlon, E. G., \& Zimmer-Gembeck, M. J. (2012). Career barriers and reading ability as correlates of career aspirations and expectations of parents and their children. Journal of Vocational Behavior, 70(2). https://doi.org/https://doi.org/10.1016/j.jvb.2006.11.001.

Dafit, F., Mustika, D., \& Melihayatri, N. (2020). Pengaruh Program Pojok Literasi Terhadap Minat Baca Mahasiswa. Jurnal Basicedu, 4(1). https://doi.org/10.31004/basicedu.v4i1.307.

Daheri, M., Juliana, J., Deriwanto, D., \& Amda, A. D. (2020). Efektifitas WhatsApp sebagai Media Belajar Daring. Jurnal Basicedu, 4(4), 775-783. https://doi.org/10.31004/basicedu.v4i4.445.

Dewi. (2020a). Dampak COVID-19 terhadap Implementasi Pembelajaran Daring di Sekolah Dasar. Jurnal Edukatif Ilmu Pendidikan, 2(1). https://doi.org/10.31004/edukatif.v2i1.89.

Dewi, W. A. F. (2020b). Dampak COVID-19 terhadap Implementasi Pembelajaran Daring di Sekolah Dasar. Edukatif: Jurnal Ilmu Pendidikan, 2(1), 55-61. https://doi.org/10.31004/edukatif.v2i1.89.

Durnali, M. (2020). The effect of self-directed learning on the relationship between self-leadership and online learning among university students in Turkey. Tuning Journal for Higher Education, 8(1), 129-165. http://dx.doi.org/10.18543/tjhe-8(1)-2020pp129-165 Received.

Fitri, J. (2019). Minat Baca Dan Kebiasaan Mencontek Dalam Hasil Belajar Memahami Teks Diskusi Siswa Kelas IX SMP N 1 Pariaman. Jurnal Bahasa Indonesia, Sastra, Dan Pengajarannya, 5(1), 31-38. http://dx.doi.org/10.26740/jpi.v5n1.p31-38.

Fitriyani, \& Sari. (2020). Motivasi Belajar Mahasiswa Pada Pembelajaran Daring Selama Pandemik Covid-19. Jurnal Kependidikan: Jurnal Hasil Penelitian Dan Kajian Kepustakaan Di Bidang Pendidikan, Pengajaran, Dan Pembelajaran, 6(2), 165-175. https://doi.org/10.33394/jk.v6i2.2654.

Garad, A., Al-Ansi, A. M., \& Qamari, I. N. (2021). The Role Of E-Learning Infrastructure And Cognitive Competence In Distance Learning Effectiveness During The Covid-19 Pandemic. Cakrawala Pendidikan, 40(1). https://doi.org/10.21831/cp.v40i1.33474.

Halawa, N., Ramadhan, S., \& Gani, E. (2020). Kontribusi Minat Baca Terhadap Kemampuan Membaca Pemahaman 
Siswa. Jurnal Edukasi Khatulistiwa, 3(1), 27. https://doi.org/10.26418/ekha.v2i2.32786.

Halimah. (2019). Penggunaan Media Kartu Gambar untuk Meningkatkan Kemampuan Membaca Permulaan pada Anak Tunagrahita Ringan. Jurnal Peradaban Islam, 1(1), 171-191.

Handayani, Hadi, Isbaniah, Burhan, \& Agustin. (2020). Corona Virus Disease 2019. Jurnal Respirologi Indonesia, 40(2). https://doi.org/10.36497/jri.v40i2.101.

Heldisari. (2020a). Efektivitas Metode Eurhythmic Dalcroze Terhadap Kemampuan Membaca Ritmis Notasi Musik. Jurnal Ilmiah Pendidikan \& Pembelajaran, 4(3). http://dx.doi.org/10.23887/jipp.v4i3.28223.

Heldisari, H. (2020b). Efektivitas Metode Eurhythmic Dalcroze Terhadap Kemampuan Membaca Ritmis Notasi Musik. Jurnal Ilmiah Pendidikan Dan Pembelajaran, 4(3). http://dx.doi.org/10.23887/jipp.v4i3.28223.

Junianto, D., \& Wagiran, W. (2013). Pengaruh kinerja mengajar guru, keterlibatan orang tua, aktualisasi diri dan motivasi berprestasi terhadap prestasi. Jurnal Pendidikan Vokasi, 3(3), 307-319. https://doi.org/10.21831/jpv.v3i3.1845.

Karima, R., \& Kurniawati, F. (2020). Kegiatan Literasi Awal Orang Tua pada Anak Usia Dini. Al-Athfal : Jurnal Pendidikan Anak, 6(1), 69-80. https://doi.org/10.14421/al-athfal.2020.61-06.

Kurniati, E., Nur Alfaeni, D. K., \& Andriani, F. (2020). Analisis Peran Orang Tua dalam Mendampingi Anak di Masa Pandemi Covid-19. Jurnal Obsesi : Jurnal Pendidikan Anak Usia Dini, 5(1), 241. https://doi.org/10.31004/obsesi.v5i1.541.

Lestari, W., \& Zulmiyetri, Z. (2019). Meningkatkan Kemampuan Membaca Kata Melalui Media Video Pembelajaran Bagi Anak Tunarungu. Jurnal Penelitian Pendidikan Kebutuhan Khusus, 7(1). http://ejournal.unp.ac.id/index.php/jupekhu/article/view/103014.

Malyana, A. (2020). Pelaksanaan Pembelajaran Daring Dan Luring Dengan Metode Bimbingan Berkelanjutan Pada Guru Sekolah Dasar Di Teluk Betung Utara Bandar Lampung. Pedagogia: Jurnal Ilmiah Pendidikan Dasar Indonesia, 2(1), 67-76. https://doi.org/10.52217/pedagogia.v2i1.640.

Maryani, N., Ichsan, M., \& Khairunnisa. (2017). Signifikansi Metode Guide Reading Terhadap Motivasi Belajar Siswa Dalam Teori Membaca Nyaring Guide Reading Method On Students ' Learning Motivation In Reading Loudly Lesson. Didaktika Tauhidi: Jurnal Pendidikan Guru Sekolah Dasar, 4(2), 126-139. http://dx.doi.org/10.30997/dt.v4i2.924.

Maufur, S., \& Puadah, A. (2015). Pengaruh Bimbingan Orang Tua Terhadap Kemampuan Membaca Siswa Kelas Rendah Di Sd Negeri Cimohong 02 Kecamatan Bulakamba Kabupaten Breb. Al Ibtida: Jurnal Pendidikan Guru MI, 6(1). https://doi.org/10.24235/al.ibtida.snj.v2i1.178.

Maulana, H. A., \& Hamidi, M. (2020). Persepsi Mahasiswa terhadap Pembelajaran Daring pada Mata Kuliah Praktik di Pendidikan Vokasi. Equilibrium: Jurnal Pendidikan, 8(2), 224-231. https://doi.org/10.26618/equilibrium.v8i2.3443.

Mehrsafar, A. H., Moghadam Zadeh, A., Jaenes Sánchez, J. C., \& Gazerani, P. (2021). Competitive anxiety or Coronavirus anxiety? The psychophysiological responses of professional football players after returning to competition during the COVID-19 pandemic. Psychoneuroendocrinology, 129(January), 105269. https://doi.org/10.1016/j.psyneuen.2021.105269.

Mirzon Daheri, Juliana, Deriwanto, A. D. A. (2020). Jurnal basicedu. Jurnal Basicedu, 3(2), 524-532.

Mufaziah, E., \& Fauziah, P. (2020). Kendala Orang Tua dalam Mendidik Anak Usia Dini pada Saat Pandemi Covid 19. Jurnal Obsesi, 5(2). https://doi.org/10.31004/obsesi.v5i2.746.

Muhammad, Sholichah, \& Aziz. (2019). Pengaruh Budaya Membaca Terhadap Kemampuan Berpikir Kritis Siswa Di SMP Islam Al Syukro Universal Ciputat Tahun 2019. Anragogi, 1(2), 332-343. http://doi.org/10.36671/andragogi.v1i2.61.

Nafisah, A. (2016). Arti Penting Perpustakaan Bagi Upaya Peningkatan Minat Baca Masyarakat. Libraria: Jurnal Perpustakaan, 2(2). https://doi.org/10.21043/libraria.v2i2.1248.

Ni, S., Lu, S., Lu, K., \& Tan, H. (2021). The effects of parental involvement in parent-child reading for migrant and urban families: A comparative mixed-methods study. Children and Youth Services Review, 123. https://doi.org/10.1016/j.childyouth.2021.105941.

Pertiwi, I. N., Sumarno, \& Dwi, A. (2019). Pengaruh Model Make A Match Berbantu Media Kartu Bergambar terhadap Kemampuan Membaca dan Menulis. MIMBAR PGSD Undiksha, 7(3), 261-270. http://dx.doi.org/10.23887/jjpgsd.v7i3.19412.

Pranata, I. W. (2014). Hubungan Bimbingan Belajar Orang Tua Dan Konsep Diri Dengan Hasil Belajar Matematika Siswa Kelas V Sd Gugus V Tampaksiring. Mimbar Ilmu Undiksha, 2(1). http://dx.doi.org/10.23887/jjpgsd.v2i1.3135.

Putri, R. N. (2020). Indonesia dalam Menghadapi Pandemi Covid-19. Jurnal Ilmiah Universitas Batanghari Jambi, 20(2), 705. https://doi.org/10.33087/jiubj.v20i2.1010.

Ramandanu, F. (2019). Gerakan Literasi Sekolah (GLS) Melalui Pemanfaatan Sudut Baca Kelas Sebagai Sarana Alternatif Penumbuhan Minat Baca Siswa. Jurnal Mimbar Ilmu, 24(1). http://dx.doi.org/10.23887/mi.v24i1.17405.

Rosalina, A., Widyasari, Y., Ismi, M., \& Hapsari. (2010). Peranan Orangtua Dalam Dongeng Sebelum Tidur Untuk 
Optimalisasi Kemampuan Berkomunikasi Anak Usia Dini. PSYCHO IDEA, 8(2). https://doi.org/10.30595/psychoidea.v8i2.236.

Sakti, S. A. (2021). Persepsi Orang Tua Siswa terhadap Pembelajaran Daring pada Masa Pandemi Covid 19 di Yogyakarta. Jurnal Obsesi, 6(1). https://doi.org/https://doi.org/10.31004/obsesi.v6i1.804.

Salma, \& Mudzanatun. (2019). Analisis Gerakan Literasi Sekolah Terhadap Minat Baca Siswa Siswa Sekolah Dasar. Mimbar PGSD Undiksha, 7(2), 122-127. http://dx.doi.org/10.23887/jjpgsd.v7i2.17555.

Saputro, L. (2019). Pengaruh Penggunaan Media Gambar Terhdap Hasil Belajar Siswa Kelas IV. Jurnal Ilmu Pendidikan, 19(1), 37-43. https://journal.unismuh.ac.id/index.php/jrpd/article/view/1238.

Sari, P. A. P. (2020). Hubungan Literasi Baca Tulis Dan Minat Membaca Dengan Hasil Belajar Bahasa Indonesia. Journal for Lesson and Learning Studies, 3(1), 141-152. http://dx.doi.org/10.23887/jlls.v3i1.24324.g14714.

Shaik Alavudeen, S., Easwaran, V., Iqbal Mir, J., Shahrani, S. M., Ali Aseeri, A., Abdullah Khan, N., ... Abdullah Asiri, A. (2021). The influence of COVID-19 related psychological and demographic variables on the effectiveness of e-learning among health care students in the southern region of Saudi Arabia. Saudi Pharmaceutical Journal. https://doi.org/10.1016/j.jsps.2021.05.009.

Soekirno. (2011). Memberdayakan Perpustakaan Dan Budaya Baca Indonesia. Baca: Jurnal Dokumentasi Dan Informasi, 21(3). https://doi.org/10.14203/j.baca.v21i3-4.280.

Suastariyani, N. K. N., \& Tirtayani, L. A. (2020). Survei Persepsi Orang Tua Mengenai Program Paud Inklusi Di Kota Denpasar Tahun 2020. Jurnal Pendidikan Anak Usia Dini Undiksha, 8(2). http://dx.doi.org/10.23887/paud.v8i2.25156.

Ulfah, A. A., \& Rahmah, E. (2017). Pembuatan dan Pemanfaatan Busy Book dalam Mempercepat Kemampuan Membaca untuk Anak Usia Dini di PAUD Budi Luhur Padang. Jurnal Ilmu Informasi Dan Perpustakaan, 6(1). Retrieved from http://ejournal.unp.ac.id/index.php/iipk/article/view/8121.

Wang, L., \& Liu, D. (2021). Unpacking the relations between home literacy environment and word reading in Chinese children: The influence of parental responsive behaviors and parents' difficulties with literacy activities. Early Childhood Research Quarterly, 56(3). https://doi.org/10.1016/j.ecresq.2021.04.002.

Warsihna, J. (2016). Meningkatkan Literasi Membaca Dan Menulis Dengan Teknologi Informasi Dan Komunikasi (TIK). Kwangsan, 4(2), 67-80. https://doi.org/10.31800/jtp.kw.v4n2.p67--80.

Warsihna, Jaka. (2016). Meningkatkan Literasi Membaca dan Menulis dengan Teknologi Informasi dan Komunikasi. Kwangsan, 4(2), 67 - 80. https://doi.org/https://doi.org/10.31800/jtp.kw.v4n2.p67--80.

Widodo, A., Indraswasti, D., Erfan, M., Maulyda, M. A., \& Rahmatih, A. N. (2020). Profil minat baca mahasiswa baru PGSD Universitas Mataram. Premiere Educandum, 10(1). https://doi.org/10.25273/pe.v10i1.5968.

Widyastuti, Kurniawan, S. B., \& Rintayati, P. (2021). Keterlibatan orang tua dalam pembelajaran daring selama pandemi covid-19 di sekolah dasar. Didaktika Dwija Indria, 9(449). https://jurnal.uns.ac.id/JDDI/article/view/48781.

Wijayanti, R. M., \& Fauziah, P. Y. (2020). Perspektif dan Peran Orangtua dalam Program PJJ Masa Pandemi Covid19 di PAUD. Jurnal Obsesi: Jurnal Pendidikan Anak Usia Dini, 5(2), 1304-1312. https://doi.org/10.31004/obsesi.v5i2.768.

Yoga Purandina, I. P., \& Astra Winaya, I. M. (2020). Pendidikan Karakter di Lingkungan Keluarga Selama Pembelajaran Jarak Jauh pada Masa Pandemi COVID-19. Cetta: Jurnal Ilmu Pendidikan, 3(2), 270-290. https://doi.org/10.37329/cetta.v3i2.454

Yulianingsih, W., Suhanadji, S., Nugroho, R., \& Mustakim, M. (2020). Keterlibatan Orangtua dalam Pendampingan Belajar Anak selama Masa Pandemi Covid-19. Jurnal Obsesi : Jurnal Pendidikan Anak Usia Dini, 5(2), 1138-1150. https://doi.org/10.31004/obsesi.v5i2.740.

Zhao, Y., \& Wu, X. (2021). Impact of visual processing skills on reading ability in Chinese deaf children. Research in Developmental Disabilities, 113. https://doi.org/10.1016/j.ridd.2021.103953. 